\title{
Use of mechanically-activated kaolin to replace ball clay in engobe for a ceramic tile
}

\section{(Utilização de caulim ativado mecanicamente em substituição a ballclay em engobe de revestimento cerâmico)}

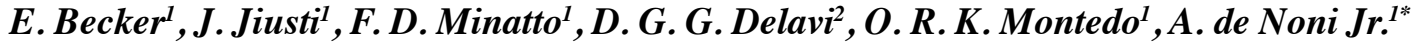 \\ ${ }^{\prime}$ Programa de Pós-Graduação em Ciência e Engenharia de Materiais, Universidade do Extremo Sul \\ Catarinense, Av. Universitária 1105, C.P. 3167, Criciúma, SC, Brazil 88806-000 \\ ${ }^{2}$ Programa de Pós-Graduação em Ciência e Engenharia de Materiais, Universidade Federal de Santa Catarina, \\ C.P. 476, Florianópolis, SC, Brazil 88040-900 \\ ederbecker@gmail.com,jeaninijiusti@gmail.com,flavia.dagostimminatto@gmail.com, \\ deysegonzaga@hotmail.com,oscar.rkm@gmail.com,*agenordenoni@unesc.net
}

\begin{abstract}
Ceramic engobe is an intermediate layer between the substrate and the glaze of a ceramic tile. It is basically composed by plastic material, clays, and non-plastic material, feldspar and frit. Light-colored clays with good plasticity and low-fire temperature are used in ceramic engobe formulations, typically ball clays. However, these clays contain different accessory minerals, which can adversely affect the opacity and the whiteness. The use of washed kaolin, with a lower content of accessory minerals, tends to lead to higher opacity and whiteness. In addition, its mechanical activation can increase the plasticity, allowing its use as a replacement for ball clay. The aim of this study was to investigate the effect of the use of mechanically-activated kaolin to replace ball clay in an engobe employed in the production of ceramic tiles. Samples of kaolin were activated by high energy mill ( 1 and $4 \mathrm{~h}$, at $500 \mathrm{rpm})$ and characterized by surface area and particle size measurements, crystallography, infrared spectroscopy and differential scanning calorimetry. Cylindrical specimens of four ceramic engobe formulations were submitted to splitting tensile strength and bulk density tests. The specimens were fired in a laboratory kiln and characterized through the determination of water absorption, bulk density, relative density and by reflectance spectrophotometry. Crystallographic analysis with Rietveld refinement and microstructural analysis by scanning electron microscopy were also carried out. After the high energy milling, the kaolin had less crystallinity and the specific surface area increased from 4.6 to $46.1 \mathrm{~m}^{2} / \mathrm{g}$. The use of mechanically-activated kaolin as a replacement for ball clay in a ceramic engobe increased the mechanical strength, crystalline phase content and whiteness.
\end{abstract}

Keywords: kaolin, ball clay, ceramic engobe, mechanical activation.

Resumo

O engobe cerâmico é uma camada intermediária entre o substrato e o esmalte de um revestimento cerâmico. É composto basicamente de material plástico, argilas, e material não plástico, feldspato e frita. Argilas claras, de boa plasticidade e fundência são utilizadas na formulação de engobes cerâmicos, tipicamente ballclay. Contudo, estas argilas possuem em suas composições diferentes minerais acessórios que podem prejudicar a opacidade e a alvura. O emprego de caulim lavado, com menor teor de minerais acessórios, tende a desenvolver maior opacidade e alvura. Além disso, sua ativação mecânica poderia aumentar a plasticidade, possibilitando a substituição da ballclay. O objetivo deste trabalho foi estudar o efeito da utilização de caulim ativado mecanicamente em substituição a ballclay em um engobe empregado na produção de revestimentos cerâmicos. Amostras de caulim foram ativadas por moagem de alta energia (1 e 4 h, a 500 rpm) e caracterizadas por meio de medidas de área de superfície específica, tamanho de partícula, cristalografia, espectrometria no infravermelho e calorimetria de varredura. Corpos de prova a verde de quatro formulações de engobe cerâmico foram submetidos aos ensaios de resistência mecânica à compressão diametral e densidade aparente. Os corpos de prova foram queimados em forno de laboratório e caracterizados, por meio da determinação de absorção de água, densidade aparente, densidade relativa e espectrofotometria de reflectância. Também foram realizadas análise cristalográfica com refinamento Rietveld e análise microestrutural em microscópio eletrônico de varredura. A moagem de alta energia tornou o caulim mais amorfo e aumentou a área de superfície específica de 4,6 para 46,1 $\mathrm{m}^{2} / \mathrm{g}$. A utilização do caulim ativado mecanicamente em substituição a ballclay no engobe cerâmico aumentou a resistência mecânica, o teor de fases cristalinas e a alvura.

Palavras-chave: caulim, ballclay, engobe cerâmico, ativação mecânica.

\section{INTRODUCTION}

The manufacturing of ceramic tiles by single-firing involves a continuous process which can be divided into four main stages: preparation of the mixture, shaping of the piece, glazing and firing [1]. During the glazing process a 
layer of ceramic engobe is applied onto the ceramic piece followed by a layer of glaze. This manufacturing process is used worldwide to produce wall and floor tiles. In this process, white glazes are traditionally used, since they are associated with hygiene and cleanliness. This attribute is very important for most applications, particularly ceramic tiles for uses such as hospital walls, recuperation centers, etc. [2]. Thus, to achieve a performance suitable for the intended use, the ceramic engobe must have a good opacity and whiteness. A ceramic engobe consists of a mixture of plastic materials (clay minerals) and non-plastic materials (typically flux agents such as frit and feldspars, and others used as opacifiers and for the correction of the thermal expansion coefficient). The function of ceramic engobes is to hide the color of the support, make waterproof the piece and allow the application of a thinner glaze layer, reducing the overall cost of the product $[3,4]$. The impermeability is directly related to the fluxing content and viscosity at high temperature. The opacity is due to the crystalline phases with refraction indexes which differ from that of the vitreous matrix [5]. However, a typical problem of ceramic engobes which are permeable and have low opacity is related to water marks due to the penetration of water through the ceramic tile [6].

Kaolin and ball clay are typically used in ceramic engobes, forming the plastic fraction of the composition $[3,7]$. The plastic fraction allows a ceramic engobe with suitable rheological behavior for its wet application to be obtained. Also, the tile has greater mechanical strength and adherence avoiding the formation of cracks before firing [8]. Kaolin of commercial interest is a processed material mainly composed by kaolinite $[9,10]$. Ball clays are materials mined from sedimentary deposits, composed of fine particles $(0.1$ to $1.0 \mu \mathrm{m})$ [11]. They are mainly composed by kaolinite and illite along with accessory minerals such as quartz, feldspar and other oxides [12]. Thus, ball clay has attracted interest since it has higher plasticity and fluxing capacity than the kaolin. The accessory minerals present in ball clay affect the whiteness and opacity of ceramic engobes. Quartz, which has a refraction index close to that of the vitreous matrix, does not contribute to the opacity. Iron and titanium oxides reduce the whiteness since they result colorant phases [13]. On the other hand, processed kaolin has lower contents of accessory minerals than ball clay. Its use as a replacement for ball clay can increase the whiteness and opacity. However, its use is limited by the greater refractoriness and lower plasticity, due to the larger particle size.

The properties of clay minerals are strongly dependent on the size and shape of the particles, which can be altered by mechanical processing such as high energy milling [14]. Thus, mechanical activation in friction mills or planetary mills with microspheres $(0.2$ to $5.0 \mathrm{~mm})$ as the grinding medium can be used to obtain submicrometric particles $[15,16]$. In this way, the particle size range of ball clay can be achieved through the mechanical activation of kaolin, reaching equivalent levels of plasticity and fluxing. In this context, the objective of this study was to investigate the effect of mechanically-activated kaolin, used to replace ball clay, on the whiteness and fluxing of an engobe used in the production of ceramic tiles.

\section{MATERIALS AND METHODS}

Samples of the raw materials typically used in the production of ceramic engobes were selected (frit, quartz, feldspar, zirconium silicate, alumina, ball clay and washed kaolin; Novacolor, Brazil). The chemical compositions of the raw materials were determined by X-ray fluorescence spectrometry (XRF, Philips PW 2400, Netherlands). Samples of mechanically-activated kaolin were obtained by high energy milling (planetary ball mill, Retsch PM100, Germany; $500 \mathrm{~mL}$ zirconium grinding jar, $650 \mathrm{~g}$ of zirconium spheres with diameters between 300 and $400 \mu \mathrm{m}$, rotation speed of $500 \mathrm{rpm}$ ) with grinding times of 1 and $4 \mathrm{~h}$. Each batch of

Table I - Mixture design (wt $\%$ ) of the ceramic engobes.

[Tabela I - Formulações (\% em massa) dos engobes cerâmicos testados.]

\begin{tabular}{ccccc}
\hline Raw material & E.BC & E.K.0h & E.KA.1h & E.KA.4h \\
\hline Non-plasticizers & & & & \\
Frit & 35 & 35 & 35 & 35 \\
Quartz & 25 & 25 & 25 & 25 \\
Feldspar & 15 & 15 & 15 & 15 \\
Zirconium silicate & 5 & 5 & 5 & 5 \\
Alumina & 5 & 5 & 5 & 5 \\
\hline Plasticizers & & & & \\
Ball clay (BC) & 10 & - & - & - \\
Kaolin at 0 h (K.0h) & 5 & 15 & - & - \\
Activated kaolin at 1 h (E.KA.1h) & - & - & 15 & - \\
Activated kaolin at 4 h (E.KA.4h) & - & - & - & 15 \\
\hline
\end{tabular}


grinding was carried out with $100 \mathrm{~g}$ of kaolin and $100 \mathrm{~g}$ of water. Sodium tripolyphosphate was added as a dispersing agent at the beginning of the grinding $(0.5 \mathrm{~g})$ and then at every $30 \mathrm{~min}(0.15 \mathrm{~g})$. The other raw materials were ground separately in a porcelain planetary mill (balls of $10 \mathrm{~mm}$, rotation speed of $100 \mathrm{rpm}$ ) until all of the material passed through a sieve aperture of $44 \mu \mathrm{m}$. The determination of the particle size was carried out by the sedimentation method (SediGraph 5000d, USA) and the specific surface area by the BET method (Micromeritics ASAP 2020, USA) for the asreceived kaolin, ball clay and mechanically-activated kaolin. To evaluate the alteration in the kaolinite structure caused by the mechanical activation, the ground kaolin samples were submitted to differential scanning calorimetry, Fourier transform infrared spectroscopy and thermogravimetry tests (DSC/TG, TA Instruments SDT Q 600, USA; heating rate of $10{ }^{\circ} \mathrm{C} / \mathrm{min}$ in air) and X-ray diffraction (XRD) with Rietveld refinement (Shimadzu XRD-6000, Japan; CuK $\alpha$ radiation, velocity $0.02 \%$ s).

The compositions of the ceramic engobes prepared are shown in Table I. The raw materials were mixed and aqueous suspensions of each composition were prepared (solids content of $50 \mathrm{wt} \%$ ). The ceramic engobe suspensions obtained were dried in an oven at $110^{\circ} \mathrm{C}$ and then humidified with $6 \mathrm{wt} \%$ of water in order to prepare the specimens for pressing at a pressure of $45 \mathrm{MPa}$. Determination of the splitting tensile strength of dry cylindrical specimens was carried out according to ASTM C496/C496M-11, while the bulk density $\left(\mathrm{d}_{\text {bulk }}\right)$ of the dry ceramic engobes was determined using the Archimedes Principle with water immersion at $20^{\circ} \mathrm{C}$, after waterproofing with paraffin. The specimens were then fired in a laboratory muffle furnace at $1110,1130,1150$ and $1170{ }^{\circ} \mathrm{C}\left(20^{\circ} \mathrm{C} / \mathrm{min}\right.$ of heating rate; 5 min holding time), followed by cooling to room temperature $\left(50^{\circ} \mathrm{C} / \mathrm{min}\right)$. After firing, the specimens were analyzed by spectrophotometry (Color-Guide BYK Gardner $\mathrm{GmbH}$, Germany), and water absorption and bulk density tests. For the specimens fired at $1130{ }^{\circ} \mathrm{C}, \mathrm{He}$-pycnometry to determine the true density (Quantachrome Ultrapic 1200e, USA), XRD with Rietveld refinement (Shimadzu XRD-6000, Japan; $\mathrm{CuK} \alpha$ radiation, velocity $0.02 \%$ s) and microstructural analysis by scanning electron microscopy (SEM, Zeiss EVO MA1O, Germany) were carried out.

\section{RESULTS AND DISCUSSION}

Table II shows the chemical composition of the raw materials employed. It can be observed that the kaolin had lower contents of colorant oxides $\left(\mathrm{TiO}_{2}\right.$ and $\left.\mathrm{Fe}_{2} \mathrm{O}_{3}\right)$ and flux oxides $\left(\mathrm{Na}_{2} \mathrm{O}, \mathrm{K}_{2} \mathrm{O}, \mathrm{CaO}\right.$ and $\left.\mathrm{MgO}\right)$ than the ball clay. $\mathrm{A}$ white borosilicate frit with calcium and zirconium oxides was used. The feldspar selected was typically sodiumpotassium based. The other raw materials had a degree of purity compatible with application in ceramic engobes. Fig. 1 shows the XRD patterns for the ball clay and the as-received kaolin. The ball clay was mainly comprised of kaolinite, illite/muskovite and quartz while the kaolin was basically composed by kaolinite. These results are in agreement with the chemical compositions shown in Table II.

The XRD patterns for the as-received kaolin $(0 \mathrm{~h})$ and kaolin obtained after mechanical activation for 1 and $4 \mathrm{~h}$ are given in Fig. 2. These patterns show a reduction in the intensity of the kaolinite peaks with an increase in the activation time, indicating a loss of the crystalline structure of kaolinite. The reduction in crystallinity was confirmed by the Rietveld refinement. The as-received kaolin showed $87 \%$ of crystallinity, while after 1 and $4 \mathrm{~h}$ the values were $48 \%$ and $34 \%$, respectively. Fig. 3 shows the FTIR spectra of kaolin as received and after activation, that present typical structure of the kaolinite according to described by several authors

Table II - Chemical composition (wt\%) of the used raw materials.

[Tabela II - Composição química (\% em massa) das matérias-primas utilizadas.]

\begin{tabular}{cccccccc}
\hline Oxides & Ball clay & Kaolin & Frit & Quartz & Feldspar & Zirconium silicate & Alumina \\
\hline $\mathrm{SiO}_{2}$ & 62.5 & 45.4 & 57.1 & 98.6 & 66.2 & 32.4 & 2.5 \\
$\mathrm{Al}_{2} \mathrm{O}_{3}$ & 25.0 & 39.4 & 5.1 & 1.0 & 18.8 & 1.9 & 94.8 \\
$\mathrm{TiO}_{2}$ & 1.3 & 0.4 & 0.1 & 0.0 & 0.0 & 0.2 & 0.0 \\
$\mathrm{Fe}_{2} \mathrm{O}_{3}$ & 0.9 & 0.6 & 0.1 & 0.0 & 0.1 & 0.1 & 0.0 \\
$\mathrm{CaO}$ & 0.1 & 0.1 & 10.5 & 0.0 & 0.2 & 0.1 & 0.1 \\
$\mathrm{MgO}$ & 0.3 & 0.0 & 2.5 & 0.1 & 0.0 & 0.1 & 0.0 \\
$\mathrm{~K}_{2} \mathrm{O}$ & 2.3 & 0.1 & 1.6 & 0.1 & 10.7 & 0.1 & 0.0 \\
$\mathrm{Na}_{2} \mathrm{O}$ & 0.4 & 0.1 & 3.7 & 0.0 & 3.9 & 0.1 & 0.4 \\
$\mathrm{MnO}$ & 0.0 & 0.0 & 0.0 & 0.0 & 0.0 & 0.1 & 0.0 \\
$\mathrm{P}_{2} \mathrm{O}_{5}$ & 0.1 & 0.0 & 0.1 & 0.0 & 0.1 & 0.2 & 0.0 \\
$\mathrm{~B}_{2} \mathrm{O}_{3}$ & - & - & 8.9 & - & - & - & - \\
$\mathrm{ZrO}_{2}$ & - & - & 10.3 & - & - & 64.3 & - \\
Loss on ignition & 7.1 & 13.9 & 0.0 & 0.2 & - & 0.4 & 2.2 \\
\hline
\end{tabular}




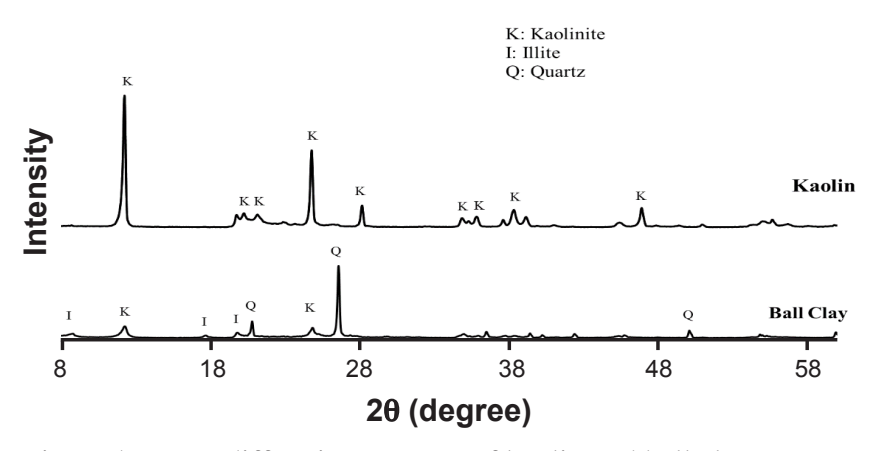

Figure 1: X-ray diffraction patterns of kaolin and ball clay.

[Figura 1: Difratogramas de raios $X$ do caulim e da argila ballclay.]

$[17,18]$. The two kind of hydroxyl groups present in kaolin, (i) outer hydroxyl group and (ii) inner hydroxyl group, were identified as $\mathrm{OuOH}$ and $\mathrm{InOH}$. Three peaks referred to the vibrational band of $\mathrm{OuOH}$ at about 3692,3670 and $3651 \mathrm{~cm}^{-1}$ and one narrow peak at $3620 \mathrm{~cm}^{-1}$ related to InOH were identified $[17,18]$. One can also observe the vibrational bands of $\mathrm{Al} / \mathrm{OHou}$ bond $\left(936 \mathrm{~cm}^{-1}\right), \mathrm{Al} / \mathrm{OHin}$ bond $\left(911 \mathrm{~cm}^{-1}\right)$ and $\mathrm{Si} / \mathrm{O}$ bond at $1113 \mathrm{~cm}^{-1}$ ( $\mathrm{Si}$ showing apical oxygen in the same plan of $\mathrm{OH}$ ), 1028 and 1005 $\mathrm{cm}^{-1}$ (Si showing basal oxygen) and three vibrating bands at $788 \mathrm{~cm}^{-1}$ (Si showing basal oxygen), 752 and $688 \mathrm{~cm}^{-1}$ (Si showing apical oxygen) [18]. After $1 \mathrm{~h}$ milling, changes in the FTIR spectra could not be observed. Peaks at 3444 and $1630 \mathrm{~cm}^{-1}$ related to molecules of absorbed $\mathrm{H}_{2} \mathrm{O}$ were identified in the $4 \mathrm{~h}$ milling sample. It has been suggested that such molecules of $\mathrm{H}_{2} \mathrm{O}$, probably from the atmosphere, substitute the hydroxyl groups of kaolinite [17].

Fig. 4 shows the mass loss with an increase in temperature for kaolin with and without activation. A longer activation time led to the onset of dehydroxylation of the kaolinite at lower temperatures. According to [17], this behavior can be attributed to the breaking of the hydrogen bonds between adjacent kaolinite layers during the activation. Fig. 5 shows the DSC thermograms for kaolin samples subjected to activation for different periods of time. The intensity of the exothermic peak associated with the nucleation of mullite

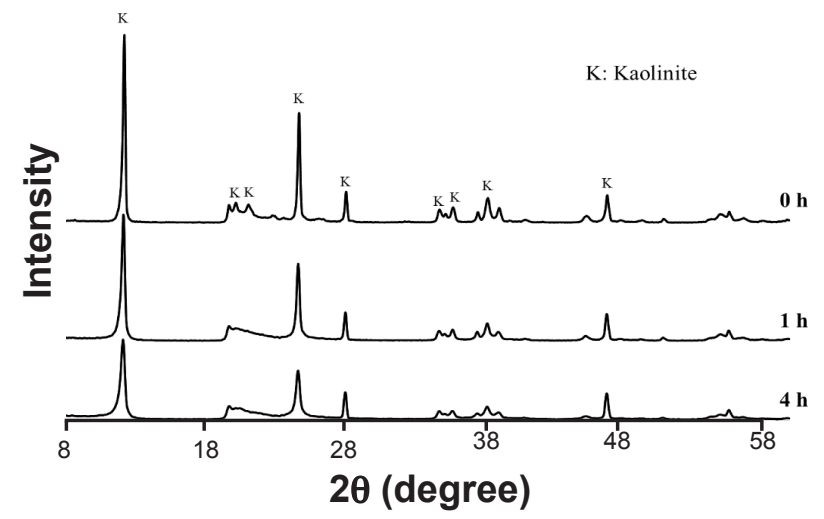

Figure 2: X-ray diffraction patterns of the kaolin activated at different grinding times.

[Figura 2: Difratogramas de raios $X$ do caulim após diferentes tempos de moagem.]
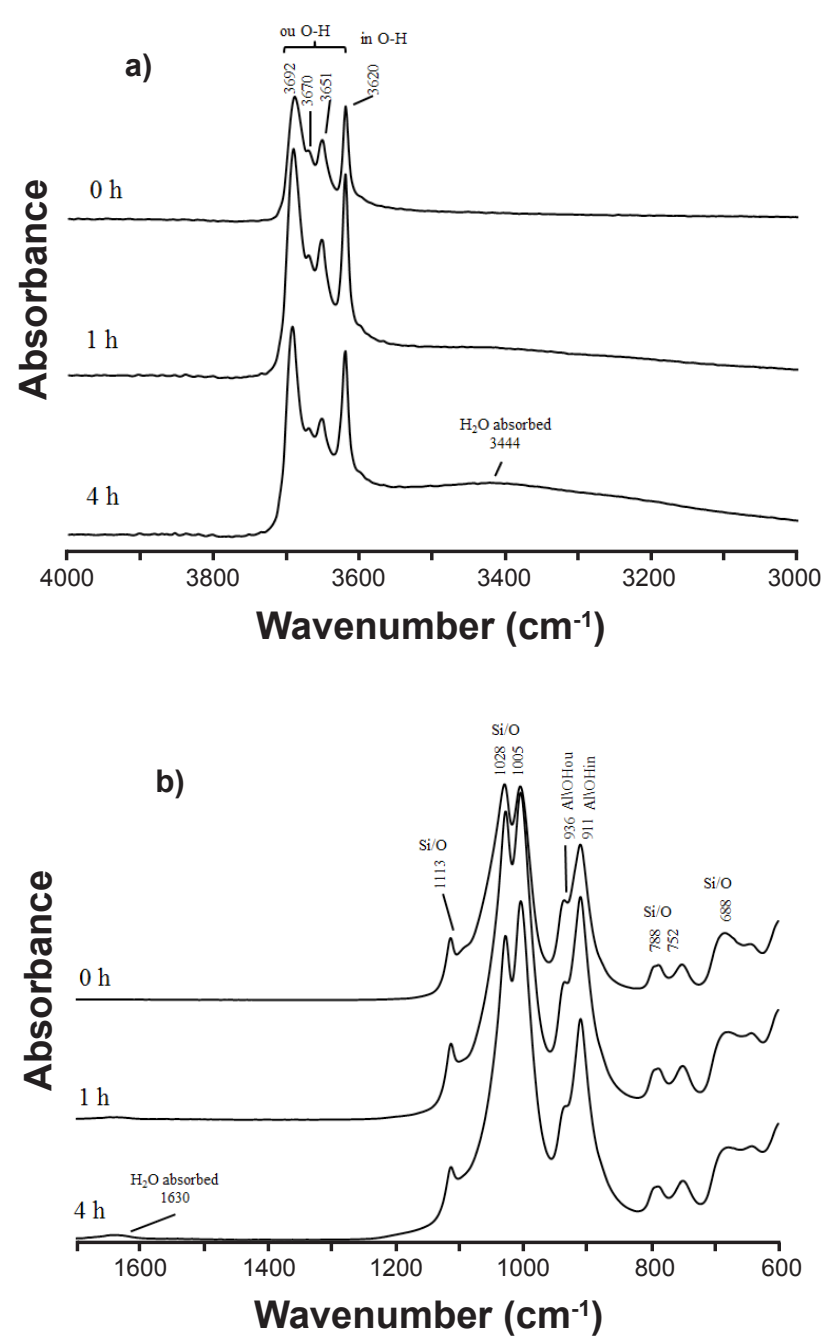

Figure 3: FTIR spectra of the kaolin activated at different grinding times at wavenumber range of: (a) 4000 to $3000 \mathrm{~cm}^{-1}$; and (b) 1700 to $600 \mathrm{~cm}^{-1}$.

[Figura 3: Espectros de FTIR do caulim após diferentes tempos de moagem na faixa de número de onda de: (a) 4000 a $3000 \mathrm{~cm}^{-1}$; e (b) 1700 a $600 \mathrm{~cm}^{-1}$.]

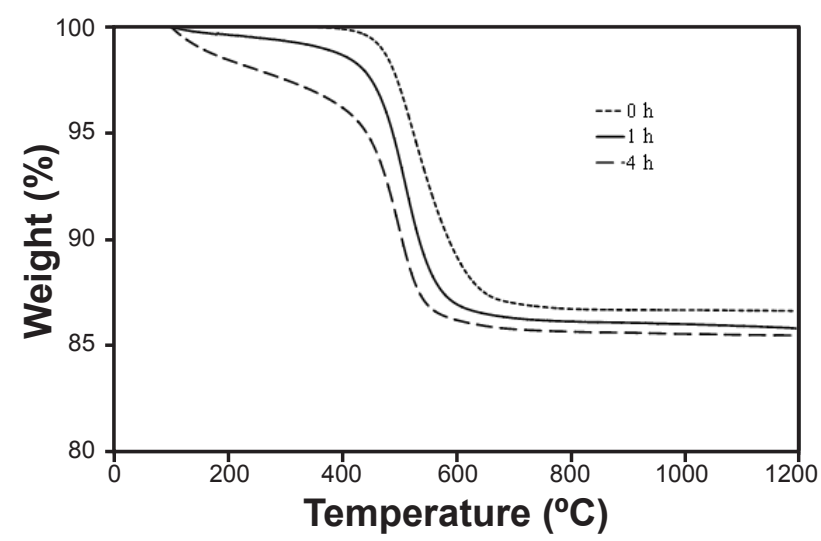

Figure 4: TGA thermograms of the kaolin activated at different grinding times.

[Figura 4: Curvas de análise termogravimétrica do caulim após diferentes tempos de moagem.] 


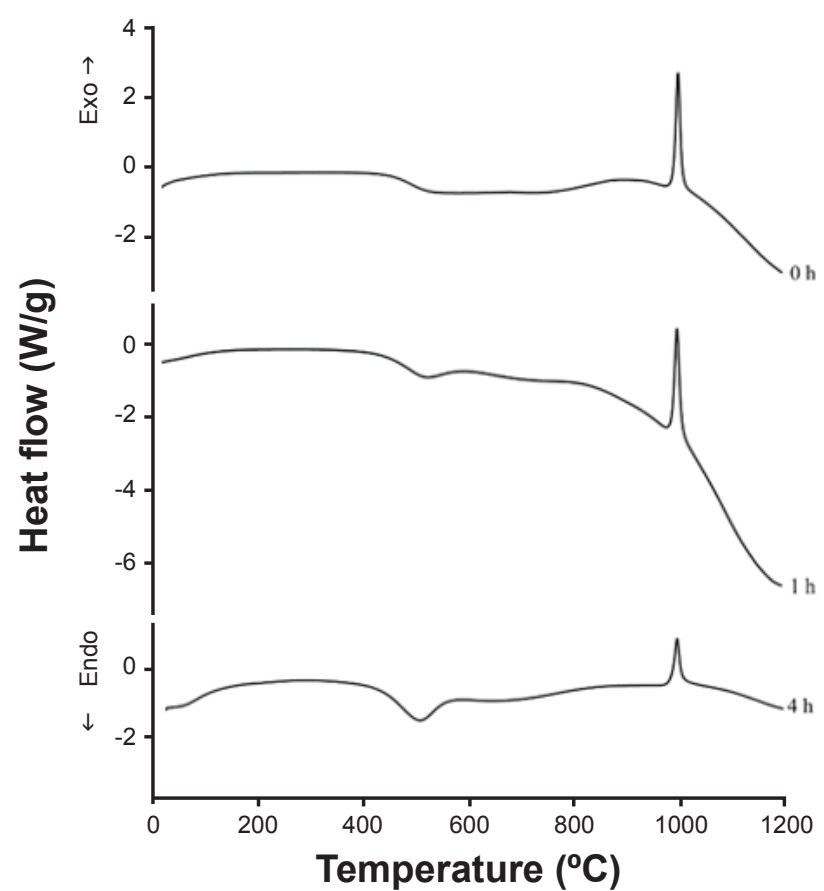

Figure 5: DSC thermograms of the kaolin activated at different grinding times.

[Figura 5: Termogramas de DSC do caulim após diferentes tempos de moagem.]

(at around $1000{ }^{\circ} \mathrm{C}$ ) was reduced with an increase in the activation time.

Table III shows the values for the specific surface area and the particle size distribution data for the ball clay and for the kaolin samples with and without mechanical activation. The activation reduced the average particle size $\left(\mathrm{D}_{50}\right)$. The activated kaolin samples had a smaller particle size compared with the ball clay and consequently a significant increase in the specific surface area was observed. Even applying $1 \mathrm{~h}$ of grinding the kaolin had a larger specific surface area than the ball clay. On comparing the kaolin samples subject to 1 and $4 \mathrm{~h}$ of activation it was observed that the specific surface area increased with the activation time. However, it was not possible to differentiate a significant effect of the activation time applied on the particle size distribution.
Fig. 6 shows a graph of the dry-bulk density and the splitting tensile strength of the engobe formulations as a function of the specific surface area of the plastic fraction of the composition. On comparing the reference engobe (E.BC) with the engobe test sample (E.K.Oh) in which the ball clay was replaced with kaolin without activation, a lower performance in terms of bulk density and mechanical strength was observed. With the mechanical activation of kaolin an increase in these properties was obtained. The values were higher than those observed with the use of ball clay. The increase in the density is related to enhanced package of the particles due to the smaller particle size. The increase in the mechanical strength is directly associated with the bulk density. The linearity verified for both behaviors demonstrated that the specific surface area is a suitable parameter for estimating the gains achieved, in terms of performance, with the mechanical activation of kaolin.

Table IV shows the water absorption values for the ceramic engobe fired at different temperatures. The results indicate that in the range of 1130 to $1170{ }^{\circ} \mathrm{C}$ there is no

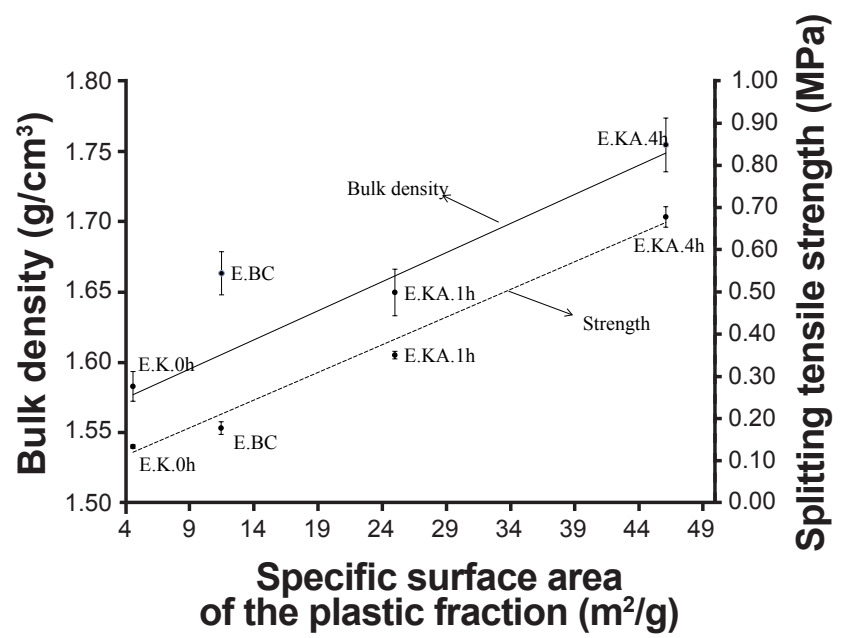

Figure 6: Effect of the specific surface area of the plastic fraction on the splitting tensile strength and bulk density of the dry ceramic engobes.

[Figura 6: Efeito da área de superfície específica da fração plástica na resistência mecânica por compressão diametral e densidade aparente dos engobes a seco.]

Table III - Particle size distribution data and specific surface area of the ball clay, as-received kaolin and activated kaolins.

[Tabela III - Dados de distribuição granulométrica e área de superfície específica da ballclay, caulim original e caulins ativados.]

\begin{tabular}{lccccc}
\hline & Ball clay & Kaolin & \multicolumn{2}{c}{ Activated kaolin } \\
& BC & K.0h & KA.1h & KA.4h \\
\hline \multirow{3}{*}{ Particle size } & $\mathrm{D}_{50}(\mu \mathrm{m})$ & 1.40 & 2.90 & 0.37 & 0.33 \\
& $<10 \mu \mathrm{m}$ & $89 \%$ & $99 \%$ & $100 \%$ & $100 \%$ \\
& $<1 \mu \mathrm{m}$ & $42 \%$ & $3 \%$ & $96 \%$ & $96 \%$ \\
Specific surface area $\left(\mathrm{m}^{2} / \mathrm{g}\right)$ & $14.9 \pm 0.1$ & $4.6 \pm 0.1$ & $25.0 \pm 0.3$ & $46.1 \pm 0.7$ \\
\hline
\end{tabular}


Table IV - Water absorption (\%) of the ceramic engobes fired at different temperatures.

[Tabela IV - Absorção de água (\%) dos engobes cerâmicos queimados em diferentes temperaturas.]

\begin{tabular}{ccccc}
\hline Engobe & $1110^{\circ} \mathrm{C}$ & $1130{ }^{\circ} \mathrm{C}$ & $1150{ }^{\circ} \mathrm{C}$ & $1170{ }^{\circ} \mathrm{C}$ \\
\hline E.BC & $0.05 \pm 0.02$ & $0.03 \pm 0.01$ & $0.10 \pm 0.01$ & $0.07 \pm 0.02$ \\
E.K.0h & $0.21 \pm 0.03$ & $0.05 \pm 0.01$ & $0.05 \pm 0.01$ & $0.04 \pm 0.01$ \\
E.KA.1h & $0.14 \pm 0.02$ & $0.06 \pm 0.02$ & $0.04 \pm 0.01$ & $0.04 \pm 0.01$ \\
E.KA.4h & $0.15 \pm 0.01$ & $0.08 \pm 0.03$ & $0.03 \pm 0.02$ & $0.02 \pm 0.01$ \\
\hline
\end{tabular}

statistical difference between the compositions. For the firing temperature of $1110{ }^{\circ} \mathrm{C}$ lower absorption was verified for the reference composition (E.BC) and higher absorption for the composition in which kaolin $0 \mathrm{~h}$ was employed in the plastic fraction. This result indicates that the ball clay had greater fluxing capacity, as expected due to the illite fraction in its composition.

The graph in Fig. 7 shows the bulk density of the ceramic engobe samples fired at different temperatures. The density decreased with the increase in temperature for all

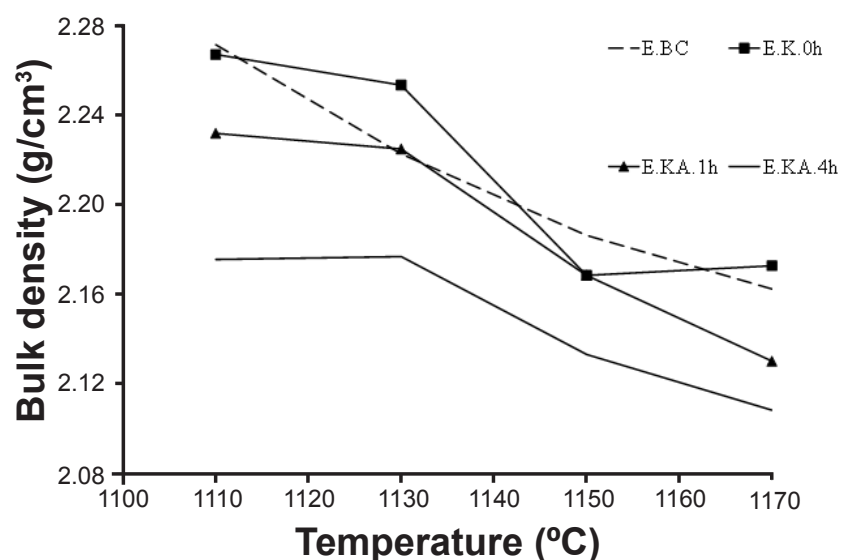

Figure 7: Bulk density of the fired samples as a function of the firing temperature.

[Figura 7: Densidade aparente das amostras queimadas em função da temperatura de queima.]

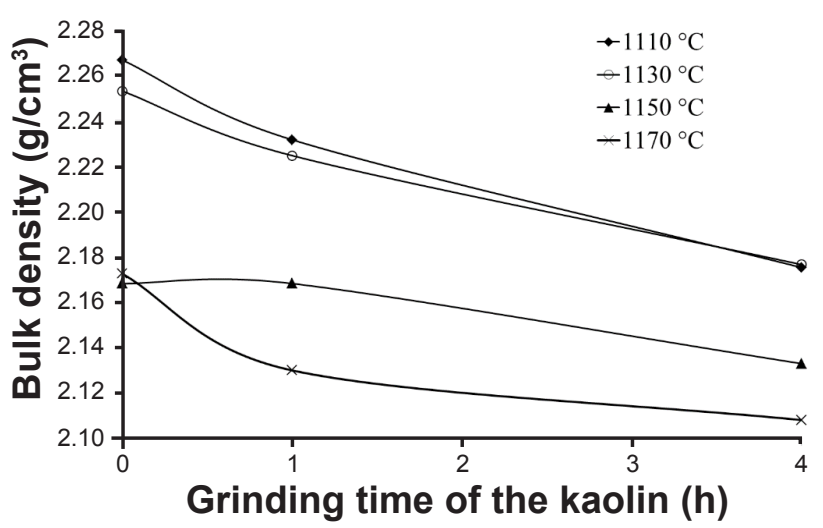

Figure 8: Bulk density of the fired samples as a function of the grinding time of the kaolin used in compositions.

[Figura 8: Densidade aparente das amostras queimadas em função do tempo de moagem do caulim utilizado nas composições.] compositions since the samples were under the conditions of expansion regime with an increase in the closed porosity in the temperature range tested, which is confirmed by the water absorption values close to zero. Thus, for the compositions where the ball clay was completely replaced with kaolin, a lower bulk density of the fired samples was associated with a higher fluxing of the composition. It was therefore observed that longer mechanical activation times led to higher fluxing effect of the composition as shown in Fig. 8.

The graph in Fig. 9 shows the values for the L color

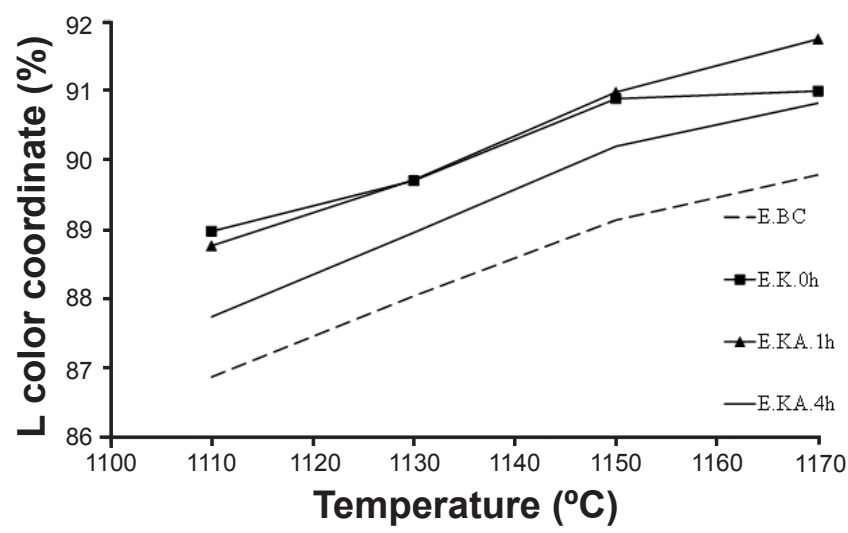

Figure 9: Lightness - L (CIElab color space) as a function of the firing temperature.

[Figura 9: Luminosidade - L (espaço de cor CIElab) em função da temperatura de queima.]

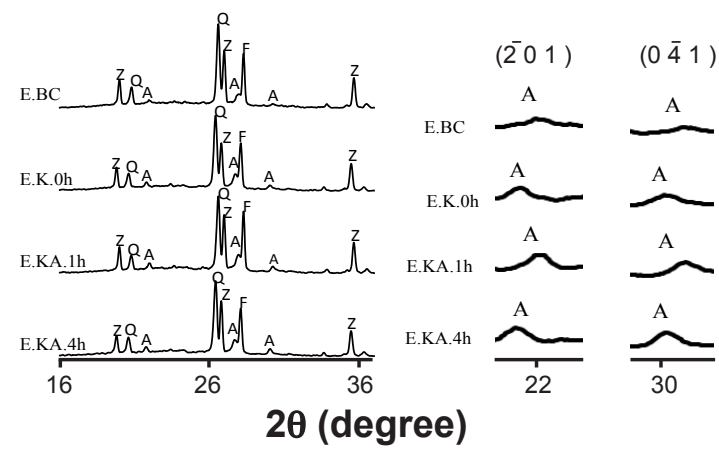

Figure 10: $\mathrm{X}$-ray diffraction patterns of the ceramic engobes fired at $1130{ }^{\circ} \mathrm{C}: \mathrm{Z}$ - zirconium silicate; Q - quartz; F - fluorite; A - anorthite (anorthite peaks were indexed with Miller indices).

[Figura 10: Difratogramas de raios $X$ dos engobes cerâmicos queimados a $1130{ }^{\circ} \mathrm{C}: \mathrm{Z}$ - silicato de zircônio; $Q$ - quartzo; $F$ fluorita; A - anortita (os picos de anortita foram indexados com índices de Miller).] 
coordinate (luminosity) of the ceramic engobes fired at different temperatures. It was observed that for the whole firing temperature range the engobe obtained employing ball clay had lower whiteness mainly due to the higher quantity of colorant oxides present in relation to kaolin (Table II). With the use of kaolin without activation and activated for $1 \mathrm{~h}$ the results observed were similar. A loss of whiteness was observed with an activation time of $4 \mathrm{~h}$.

The XRD patterns for the ceramic engobes fired at $1130{ }^{\circ} \mathrm{C}$ are shown in Fig. 10, in which zirconium silicate, quartz and anorthite crystalline phases can be identified. Fluorite is present because it was used as the internal standard for the Rietveld refinement. Anorthite was formed during the firing, due to the calcium oxide content present in the frit. Fig. 8 shows the peaks of $(\overline{2} 01)$ and $(0 \overline{4} 1)$ planes

Table V - Contents (\%) of the crystalline phases identified in ceramic engobes fired at $1130{ }^{\circ} \mathrm{C}$.

[Tabela V - Frações (\%) das fases cristalinas identificadas nos engobes cerâmicos queimados a $1130^{\circ} \mathrm{C}$.]

\begin{tabular}{cccc}
\hline Engobe & Anorthite & Quartz & $\begin{array}{c}\text { Zirconium } \\
\text { silicate }\end{array}$ \\
\hline E.BC & 7.6 & 14.8 & 7.1 \\
E.K.0h & 12.8 & 15.4 & 7.1 \\
E.KA.1h & 9.8 & 13.9 & 6.9 \\
E.KA.4h & 13.2 & 16.6 & 7.1 \\
\hline
\end{tabular}

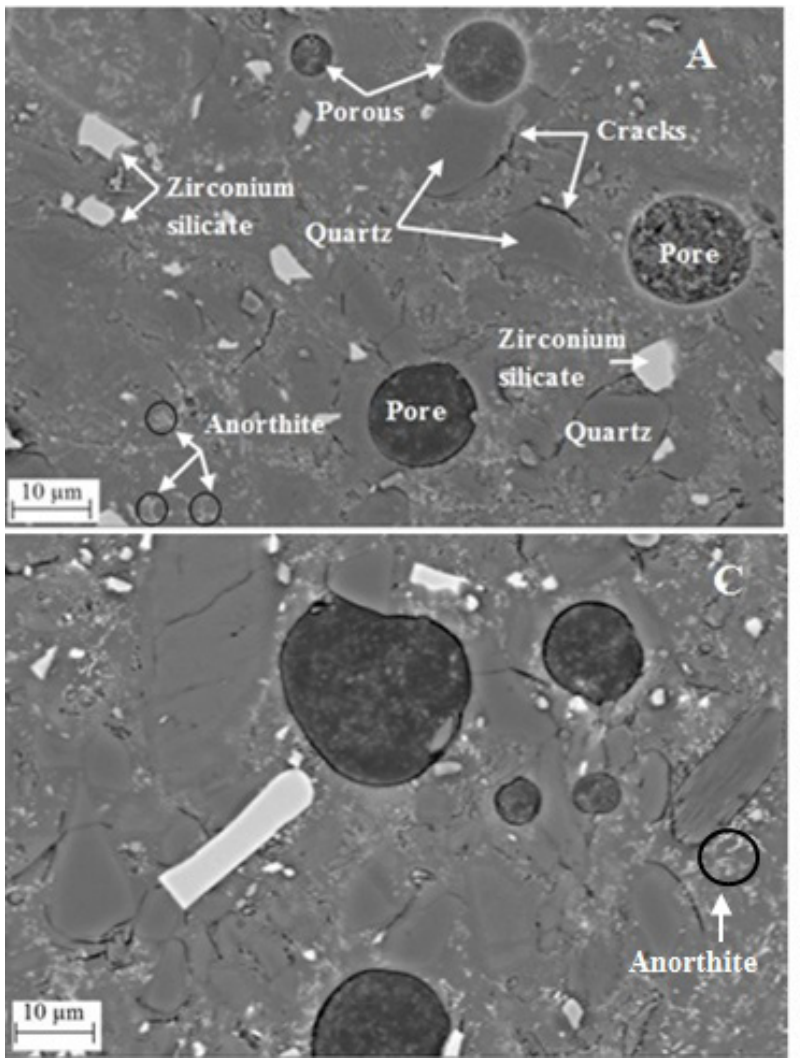

of the anorthite. It was observed that these peaks were more intense for the ceramic engobes obtained with kaolin than those prepared with ball clay, which suggests a larger proportion of this phase in the engobes obtained employing kaolin. The results for the quantification of the phases (Table V) confirm this observation. It was also observed that the fractions of quartz and zirconium silicate phases were compatible with the mixes employed. The results indicate the partial dissolution of the quartz fraction, particularly the finer particles.

Fig. 11 shows the micrographs for the ceramic engobes fired at $1130{ }^{\circ} \mathrm{C}$. They are composed of a vitreous matrix, zirconium silicate, quartz and anorthite particles, with pores and cracks around the quartz particles. The micrographs for the different samples were very similar. There is a small difference associated with the greater facility in identifying anorthite crystals in the compositions with kaolin in relation to that with ball clay. This observation is in agreement with the XRD results and the quantification of the phases. For the ceramic engobe prepared with kaolin activated for $4 \mathrm{~h}$ the formation of smaller secondary pores was also observed. The results for the relative density verified the lower value for the engobe E.KA.4h (0.84). The highest value obtained for the relative density was for the engobe E.KA.0h (0.87). The engobes E.BC and E.KA.1h had the same relative density (0.85). Table VI shows the microanalysis of the phases found in micrographs. The results obtained are in agreement with the XRD results.

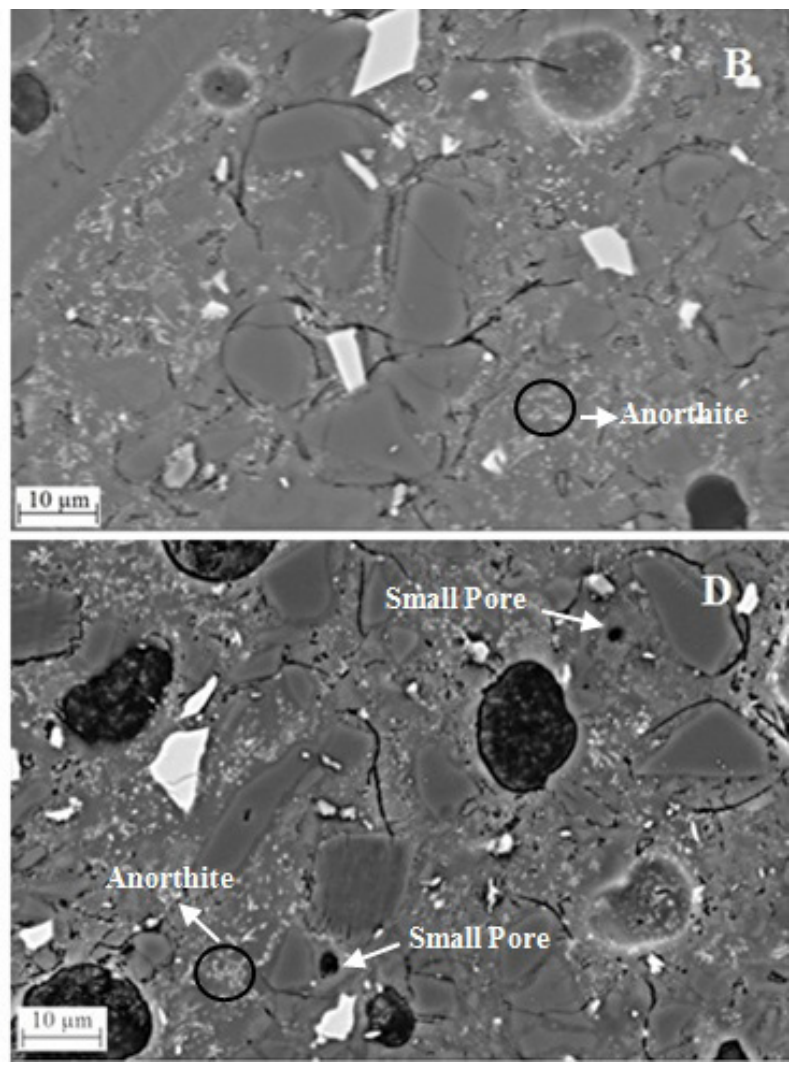

Figure 11: SEM micrographs of: (A) E.BC; (B) E.K.0h; (C) E.KA.1h; (D) E.KA.4h.

[Figura 11: Micrografias obtidas por microscopia eletrônica de varredura de: (A) E.BC; (B) E.K.Oh; (C) E.KA.1h; (D) E.KA.4h.] 
Table VI - Microanalysis of the phases found in micrographs of fired engobes.

[Tabela VI - Microanálises das fases encontradas nas micrografias dos engobes.]

\begin{tabular}{ccccc}
\hline Element & Anorthite & $\begin{array}{c}\text { Zirconium } \\
\text { silicate }\end{array}$ & Quartz & Matrix \\
\hline $\mathrm{O}$ & 48.5 & 36.5 & 53.2 & 49.8 \\
$\mathrm{Si}$ & 21.1 & 16.6 & 45.6 & 33.0 \\
$\mathrm{Al}$ & 24.5 & 2.0 & 1.2 & 10.7 \\
$\mathrm{Ca}$ & 4.9 & 1.4 & - & 4.1 \\
$\mathrm{Mg}$ & 1.0 & - & - & 0.8 \\
$\mathrm{Na}$ & - & - & - & 1.6 \\
$\mathrm{Zr}$ & - & 43.4 & - & - \\
\hline
\end{tabular}

\section{CONCLUSIONS}

In this study, a commercial washed kaolin sample was submitted to mechanical activation for 1 and $4 \mathrm{~h}$ at a rotation speed of $500 \mathrm{rpm}$ in a planetary mill with zirconium microspheres $(0.3 \mathrm{~mm})$. The thermal and mineralogical characterization demonstrated that this processing reduced the crystallinity. The particle size was reduced and the specific surface area was increased to values higher than that achieved with the studied ball clay, even applying only $1 \mathrm{~h}$ of activation. The results for the bulk density and mechanical strength (dry sample) demonstrated that on application in the engobe formulations the activated kaolin can provide a better performance than that with ball clay. In addition, since this is an industrial operation, the properties of the kaolin can be adjusted according to the requirements of the application, which makes this raw material more versatile than ball clays. The increase in the specific surface area showed a good correlation with the increase in the performance of the activated kaolin. This is a property which is relatively simple to measure and it has a single numerical value and thus it is of particular interest for the control of the mechanical activation process. In relation to the performance of the firing, the mechanical activation increased the fluxing effect of the engobe compositions. An activation time of $1 \mathrm{~h}$ was enough to obtain a sintering level similar to that obtained using ball clay. With $4 \mathrm{~h}$ of activation the fluxing effect continued to increase. This is a beneficial effect because it can reduce firing temperature. With the use of kaolin, the engobe compositions were whiter. This behavior is mainly associated with the lower content of colorant oxides. The results suggest that the use of prolonged mechanical activation can reduce the whiteness obtained with the use of kaolin. With the application of $4 \mathrm{~h}$ of activation a significant loss in the whiteness was observed. Also, the use of kaolin increased the content of crystallized anorthite phase in the fired samples. In this study the results did not allow a suitable correlation between the increase in the anorthite content and the increase in the whiteness of the engobe, although this behavior can be expected. It was demonstrated that the mechanical activation improved the properties of the commercial kaolin samples for use in ceramic engobes, allowing the total replacement of the ball clay. The gain obtained in the whiteness allows a reduction in the dosages of other raw materials employed as opacifiers.

\section{ACKNOWLEDGEMENT}

The authors are very grateful to Coordenação de Aperfeiçoamento de Pessoal de Nível Superior (CAPES) for the scholarships granted to the co-authors.

\section{REFERENCES}

[1] A. Barba Martí, Matérias-primas para a frabricación de soportes de baldosas cerámicas. $2^{\mathrm{a}}$ Ed., Inst. Tecn. Cerâmica, Castelón (2002) 19.

[2] Inst. Valenciano Edific., Guia de la baldosa cerámica: el vademecum de la baldosa cerámica, para su clasificación, su selección, materiales de agarre y rejuntado, la redacción del proyecto, el control de la obra, el uso y mantenimento, $6^{\mathrm{a}}$ Ed., Valencia (2003) 140-141.

[3] D.C. Maynald, Ceramic glazes, Borax Goldings, London (1980) 40.

[4] J. Taylor, A. Bull, Ceramics glaze technology, Pergamon Press, New York (1986) 135.

[5] A. Duran, R. Hevia, N. Centritto, A.P.N. de Oliveira, A.M. Bernardin, Introducción a los esmaltes cerámicos, Faenza Editrice Ibérica, Castellón, s.l (2002) 47.

[6] G.R. dos Santos, F.G. Melchiades, A.O. Boschi, Cerâm. Ind. 12 (2007) 22-27.

[7] N. Tozzi, Smalti ceramici: considerazioni teoriche e pratiche, Faenza Editrice, (1992) 304.

[8] J. Bort, J. Fenollosa, in III World Congr. Ceram. Tile Qual.- QUALICER, Cám. Ofic. Com., Ind. Navegac., Castellón, Vol. 2 (1994) 89-104.

[9] P. Souza Santos, Ciência e tecnologia de argilas, 2a Ed., Edgard Blücher, S. Paulo (1992) 471.

[10] A.B. da Luz, F.A.F. Lins, Rochas e minerais industriais, CETEM, Rio de Janeiro (2005) 255.

[11] F. Shackelford, R. Doremus, Ceramic and glass materials, Springer, New York (2008) 118.

[12] F. Bergaya, B. Theng, G. Lagaly, Handbook of clay science, Elsevier, Amsterdam (2006) 4.

[13] J.M.F. Navarro, El vidrio, $3^{\mathrm{a}}$ Ed., Cons. Sup. Invest. Cient., Madrid (2003) 303.

[14] G. Baudet, V. Perrotel, A. Seron, M. Stellatelli, Powder Technol. 105 (1999) 125-134.

[15] F. Wellenkamp, Moagem fina e ultrafina de minerais industriais: uma revisão, CETEM, Rio de Janeiro (1999) 18.

[16] C. Carter, M. Norton, Ceramic materials, science and engineering, Springer, New York (2007) 360.

[17] R.L. Frost, E. Makó, J. Kristóf, E. Horváth, J.T. Kloprogge, J. Colloid Interface Sci. 239 (2001) 458-466.

[18] F. Dellisanti, G. Valdrè, Int. J. Miner. Process. 102-103 (2012) 69-77.

(Rec. 01/06/2016, Rev. 15/08/2016, 16/11/2016, Ac. 